\title{
Seroprevalence of bovine herpesvirus 1 related alphaherpesvirus infections in free-living and captive cervids in Poland
}

\author{
Jerzy Rola ${ }^{\mathrm{a}, *}$, Magdalena Larska ${ }^{\mathrm{a}}$, Wojciech Socha ${ }^{\mathrm{a}}$, Jolanta G. Rola ${ }^{\mathrm{b}}$, Magdalena Materniak ${ }^{\mathrm{c}}$, \\ Renata Urban-Chmiel ${ }^{\mathrm{d}}$, Etienne Thiry ${ }^{\mathrm{e}}$, Jan F. Żmudziński ${ }^{\mathrm{a}}$ \\ a Department of Virology, National Veterinary Research Institute, Al. Partyzantów 57, 24-100, Puławy, Poland \\ b Department of Hygiene of Food of Animal Origin, National Veterinary Research Institute, Al. Partyzantów 57, 24-100, Puławy, Poland \\ ${ }^{c}$ Department of Biochemistry, National Veterinary Research Institute, Al. Partyzantów 57, 24-100, Puławy, Poland \\ d Sub-Department of Veterinary Prevention and Avian Diseases, Institute of Biological Bases of Animal Diseases, Faculty of Veterinary Medicine, University of Life Sciences, \\ Akademicka 12, Lublin, Poland \\ e Virology and Viral Diseases, Department of Infectious and Parasitic Diseases, Faculty of Veterinary Medicine, University of Liège, 4000, Liège, Belgium
}

\section{A R T I C L E I N F O}

\section{Keywords:}

Alphaherpesvirus

BoHV-1

CvHV-1

Epidemiology

Deer

\begin{abstract}
A B S T R A C T
To determine the occurrence of bovine herpesvirus 1 (BoHV-1) related alphaherpesvirus infections in cervids, 1194 serum samples of wild ruminants originating from 59 forest districts of Poland were tested with IBR gB ELISA and virus neutralization test (VNT) against BoHV-1 and cervid herpesvirus 1 (CvHV-1). The seroprevalence differed significantly between free-living and captive cervids $(P<0.001)$ with a total of 89 out of 498 $(17.9 \%)$ and 268 out of 696 (38.5\%) seropositive animals in each type of population. In free-ranging cervids, the highest seroprevalence was found among red deer (25.6\%) and in fallow deer (23.1\%), while it was the lowest in roe deer $(1.7 \%)$. The seroprevalence varied at the district level between 0 and $100 \%$ with the mean value of $17.4 \%$ (95\% CI:10.1-24.0). Additionally, seroprevalence was associated with afforestation $\left(\chi^{2}=7.5\right.$; $P=0.006)$ and to some degree with the mean of cattle density in province $\left(\chi^{2}=7.0 ; P=0.08\right)$. The mean antibody titre against CvHV-1 in VNT (161.8; 95\%CI: 146.0-177.6) has been significantly higher $(\mathrm{P}<0.0001)$ than the mean titre of BoHV-1 antibodies (10.1; 95\%CI: 8.9-11.4). The results showed that BoHV-1 related alphaherpesvirus infections are present in population of free-ranging and farmed cervids in Poland. Based on the VNT results and considering the low susceptibility of red deer to BoHV-1, it seems that the dominant alphaherpesvirus circulating in wild ruminants is most likely CvHV-1 and therefore it is rather unlikely that deer in Poland could play any role as a reservoir of BoHV-1 for cattle.
\end{abstract}

\section{Introduction}

Ruminant alphaherpesviruses form a large group of pathogens infecting various species of domestic and wild ruminants. There are at least 7 recognised ruminant alphaherpesviruses among which bovine herpesvirus 1 (BoHV-1) is the most important and best characterized (Roizmann et al., 1992; Davison, 2010). BoHV-1 can cause different clinical diseases in cattle such as infectious bovine rhinotracheitis (IBR), infectious pustular vulvovaginitis (IPV), conjunctivitis, fatal multisystemic infection of newborn calves, encephalitis and abortions (Muylkens et al., 2007; Nandi et al., 2009). The virus infects mostly cattle but also many other species of domestic and wild artiodactyls including deer (Kálmán and Egyed, 2005; Thiry et al., 2006; Intisar et al., 2009; Scicluna et al., 2010). Moreover cervid herpesvirus 1 (CvHV-1) which is related to BoHV-1 alphaherpesvirus was isolated from ocular disease in red deer (Inglis et al., 1983). In some European countries, red deer can come into contact with cattle and potentially can become infected with BoHV-1 (Mollema et al., 2005).

BoHV-1 is widespread in cattle population all over the world and cause significant economic losses. To reduce the cost of the infection, several European countries developed the eradication programs of IBR. Successful eradication of BoHV-1 depends mostly on serological tests which allow identification of infected animals. However, cross-reactions caused by ruminant alphaherpesviruses related to BoHV-1 can hamper the diagnosis and effectiveness of the eradication programs.

In Poland, BoHV-1 was isolated for the first time from cattle in the seventies of the last century (Baczyński and Majewska, 1977; Kita, 1978). In recent studies, $37.7 \%$ of dairy cows and up to $73.7 \%$ of dairy cattle herds were positive for BoHV-1 antibodies (Rola et al., 2005; Rypuła et al., 2012). There is little information on the occurrence of

\footnotetext{
* Corresponding author.

E-mail address: jrola@piwet.pulawy.pl (J. Rola).
} 
alphaherpesvirus infections in wild ruminants in the country. Most of the studies were related to European bison from the Bialowieza Primeval Forest, and the seroprevalence of alphaherpesviruses was residual (Kita and Anusz, 1991; Salwa et al., 2007; Rypuła et al., 2011a, 2011b). Therefore, the study was designed to determine the spread of alphaherpesviruses in the main cervid species in Poland. The first part of the study consisted of a screening of a representative number of samples for the presence of BoHV-1 related alphaherpesvirus antibodies using ELISA and an estimation of risk factors for the seropositivity, while further virus neutralization tests aimed at determining the virus species circulating in Polish wild and captive deer.

\section{Materials and methods}

\subsection{Sample collection}

A total of 1194 serum samples collected from 101 fallow deer (Dama dama), 896 red deer (Cervus elaphus), 23 Dybowski's sika deer (Cervus nippon hortullorum), 165 roe deer (Capreolus capreolus) were included in the study. No data on the species was available for 9 deer samples. Freeranging animals $(n=498)$, which were sampled at 59 (out of 430 ) forest districts from 13 (out of 16) Polish provinces during collective hunting of 2013/2014 season were fallow deer $(n=46)$, red deer $(n=278)$, and roe deer $(n=165)$. The captive animals $(n=696)$ belonged to the fallow $(n=55)$, red $(n=618)$ and sika $(n=23)$ species, which originated from a research centre (herd A) and two commercial herds (B and C), were sampled after mechanical immobilization. The gender data was available for 308 individuals of all deer species except for sika deer and included 236 females and 72 males.

\subsection{ELISA}

Serum samples were tested with the commercial Idexx IBR gB blocking ELISA test kit (IDEXX, Montpellier, France). The assay was performed according to manufacturer's instruction. The results were evaluated based on spectrophotometric measurement of the optical density (OD) at $450 \mathrm{~nm}$. For each sample the $\mathrm{S} / \mathrm{N}$ value was calculated using the following equation: $\frac{\text { ODsample }}{\text { ODmean negative control }} \times 100 \%$. A sample was classified as positive, doubtful or negative when the $\mathrm{S} / \mathrm{N}$ value was below or equal to $50 \%$, between $50 \%$ and $55 \%$, and above $55 \%$, respectively.

\subsection{Virus neutralization test (VNT)}

VNT was performed for 177 (172 positive and 5 doubtful in IBR $g B$ ELISA) serum samples without haemolysis derived from fallow deer $(n=7)$, red deer $(n=166)$, and roe deer $(n=4)$. The samples from free-ranging $(n=59)$ and captive $(n=118)$ cervids were among them. Additionaly, 20 randomly selected serum samples negative in IBR $\mathrm{gB}$ ELISA ( 10 from red deer and 10 from roe deer) were tested. The neutralizing titres against two alphaherpesviruses: the BoHV-1 IPV468 strain and the CvHV-1 P4 strain were determined. Prior to testing, all sera were heat inactivated at $56{ }^{\circ} \mathrm{C}$ for $30 \mathrm{~min}$. Serial two-fold dilutions of serum samples in Eagle's Minimum Essential Medium (MEM) (Sigma, St Louis, USA) were prepared in duplicate in a 96-well microplate starting from 1:2 up to 1:128. To each well, $100-300$ TCID $_{50}$ of BoHV-1 or CvHV-1 were added. Two wells per serum in the dilution 1:2 were left without virus as serum cytotoxicity controls. Microplates were incubated at $37^{\circ} \mathrm{C}$ in $5 \% \mathrm{CO}_{2}$ for $18-24 \mathrm{~h}$. Afterwards, Madin-Darby bovine kidney (MDBK) cell (ATCC CCL-22) suspension containing $10^{5}$ cells $/ \mathrm{ml}$ was added to each well and after 3 to 5 days of incubation at $37{ }^{\circ} \mathrm{C}$ in $5 \% \mathrm{CO}_{2}$ microplates were observed under microscope. Serum was considered positive if the inhibition of viral cytopathic effect (CPE) was observed in both wells at a dilution 1:2. The neutralizing titre of tested serum was assumed as the reciprocal of the highest dilution of the sample for which none or one of the wells showed CPE. Samples showing cytotoxic effect in the control wells were excluded from the analysis.

\subsection{Covariate data}

Information of species, gender, sampling date and place (name of forest district, province) were provided by the sampling protocol and recorded in the wide-format dataset. The density of wild cervids was calculated using the data including the estimated numbers of free-living cervids and the acreage of the forest district provided by the General Directorate of National Forest Holding (GDNFH, 2014) for each of 59 forest districts. The values of the variable ranged between 0.7 and 10.3 with the mean value of 4.8 (median 4.9 ) cervids $/ \mathrm{km}^{2}$. The level of afforestation which determined the proportion of forested area in the forest district ranged between 4.9 and $98.0 \%$ with the mean and median of $34.9 \%$ and $32.8 \%$, respectively (GDNFH, 2014). In order to study possible risk of spill over effect from domestic ruminants, density of cattle, which was determined as a number of animals/100 ha of agricultural areas at the province level by the Central Statistical Office (CSO, 2013a) was used in the analysis. The values of cattle density ranged between 10.2 and 86.7 with the mean and median values of 27.9 and 21.0 animals/100 ha, respectively. The urbanization rate [proportion of the county (the administrative subunit of province) population inhabiting urban areas] was introduced as an environmental factor (CSO, 2013b). The data representing the samples ranged between 0 and $68.3 \%$, with the mean and median values of $44.1 \%$ and $49.7 \%$, respectively. Since the variables were not normally distributed, they were categorized by the 25 th and 75 th centiles into three groups (the mean values, ranges and medians presented at Table 1).

\subsection{Statistical analysis}

The database prepared in Microsoft Excel has been transferred to STATA v.13.0 software (StataCorp LP, Texas, USA), where statistical analysis was performed. The seroprevalences were estimated by application of survey methods corrected by sampling weights (pweights) calculated accordingly: $1 /(n$ of tested individuals $/ N$ of free-ranging cervids per district. The last number was obtained for each forest district (GDNFH, 2014). The single-variable associations between seropositivity against alphaherpesvirus and population type (free-ranging; captive), origin (forest district), species, sex, and the other continuous and categorical covariates were estimated using Kruskal-Wallis equality of population rank test and univariable logistic regression. In order to assess the risk factors of alphaherpesvirus seropositivity in free-ranging cervids, mixed-effects logistic regression model was fitted by backward selection of insignificant (with $P>0.05)$ predictor nominal and continuous variables one-by-one. The collinearity (Spearman $\rho>|0.5| ; P<0.05$ ) between the predictors was considered when building up the multivariable model. Possible confounding and clustering was analysed as previously described by Dohoo et al. (2010). To account for clustering, models including random intercept were assessed by checking the variance of the component and other covariates. The multivariable models were compared by Akaike Information Criterion (AIC) and Bayesian Information Criterion (BIC) and the model with the lowest and highest values respectively was considered better fitting.

The mean VNT titres against BoHV-1 and CvHV-1 were compared in groups by $t$ test. A $P$ value below 0.05 was considered significant.

\section{Results}

The seroprevalence differed significantly between free-living and captive cervids with $\chi^{2}=150(P<0.001)$. Based on ELISA results, a total of 89 out of 498 (17.9\%) and 268 out of 696 (38.5\%) animals from each type of population were found seropositive. Initially, 5 sera gave 
Table 1

Descriptive statistics of the univariable analysis of the alphaherpesvirus distribution among free-ranging cervids $(n=498)$.

\begin{tabular}{|c|c|c|c|c|c|c|c|c|c|}
\hline \multirow[t]{2}{*}{ Variable } & \multirow[t]{2}{*}{ Category (values) ${ }^{\mathrm{a}}$} & \multicolumn{3}{|c|}{ Seroprevalence } & \multirow[t]{2}{*}{$\chi^{2 \mathrm{e}}$} & \multirow[t]{2}{*}{$P_{K W}^{f f}$} & \multirow[t]{2}{*}{ Odds ratio (OR) } & \multirow[t]{2}{*}{ OR 95\% CI } & \multirow[t]{2}{*}{$P_{L R}^{f}$} \\
\hline & & $n / N^{\mathrm{b}}$ & $\%^{c}$ & $95 \% \mathrm{CI}^{\mathrm{c}}{ }^{\mathrm{d}}$ & & & & & \\
\hline Species $(n=489)$ & $\begin{array}{l}\text { fallow deer (Dama dama) } \\
\text { red deer (Cervus elaphus) } \\
\text { roe deer (Capreolus capreolus) }\end{array}$ & $\begin{array}{l}11 / 46 \\
74 / 278 \\
6 / 165\end{array}$ & $\begin{array}{l}23.1 \\
25.6 \\
1.7\end{array}$ & $\begin{array}{l}10.6-43.2 \\
19.0-33.5 \\
0.7-4.2\end{array}$ & 37.1 & 0.0001 & 2.6 & $1.8-3.7$ & 0.0001 \\
\hline Sex $(n=308)$ & $\begin{array}{l}\text { female } \\
\text { male }\end{array}$ & $\begin{array}{l}44 / 236 \\
18 / 72\end{array}$ & $\begin{array}{l}12.3 \\
24.1\end{array}$ & $\begin{array}{l}8.5-17.5 \\
13.3-39.6\end{array}$ & 1.4 & 0.2 & 1.4 & $0.8-2.7$ & 0.2 \\
\hline Density of wild cervids ${ }^{g}$ & $\begin{array}{l}\text { low (mean } 2.8 \text {; median; range: } 0.7-3.8 \text {; median } 2.8 \text { ) } \\
\text { medium (mean 4.9; range: } 3.8-5.7 \text {; median } 4.9 \text { ) } \\
\text { high (mean 6.9; range: } 5.9-10.3 \text {; median } 6.7 \text { ) }\end{array}$ & $\begin{array}{l}22 / 125 \\
52 / 258 \\
20 / 115\end{array}$ & $\begin{array}{l}14.4 \\
13.8 \\
15.6\end{array}$ & $\begin{array}{l}8.9-22.7 \\
9.2-20.0 \\
6.9-31.5\end{array}$ & 0.6 & 0.7 & 1.0 & $0.7-1.4$ & 0.9 \\
\hline Level of afforestation $(\%)^{\mathrm{h}}$ & $\begin{array}{l}\text { low (mean } 16.4 \text {; range } 4.9-23.6 \text {; median } 15.1 \text { ) } \\
\text { medium (mean 33.5; range: } 23.7-47.1 \text {; median } 32.9 \text { ) } \\
\text { high (mean } 60.6 \text {; range: } 48.1-98.0 \text {; median } 57.6 \text { ) }\end{array}$ & $\begin{array}{l}17 / 141 \\
51 / 243 \\
26 / 114\end{array}$ & $\begin{array}{l}7.7 \\
14.1 \\
24.3\end{array}$ & $\begin{array}{l}4.1-13.7 \\
9.1-21.1 \\
15.4-36.2\end{array}$ & 6.1 & 0.05 & 1.4 & $1.0-2.0$ & 0.02 \\
\hline Density of domestic cattle $\mathrm{e}^{\mathrm{i}}$ & $\begin{array}{l}\text { low (mean } 12.1 \text {; range } 10.2-15.8 \text {; median } 11.3 \text { ) } \\
\text { medium (mean } 29.7 \text {; range } 17.3-41.9 \text {; median } 26.3 \text { ) } \\
\text { high (50.3; range: } 43.5-86.7 \text {; median } 43.8 \text { ) }\end{array}$ & $\begin{array}{l}38 / 141 \\
40 / 280 \\
16 / 77\end{array}$ & $\begin{array}{l}16.5 \\
11.0 \\
22.0\end{array}$ & $\begin{array}{l}9.4-27.2 \\
6.9-17.0 \\
12.5-35.8\end{array}$ & 10.0 & 0.007 & 0.7 & $0.5-1.0$ & 0.08 \\
\hline Urbanization rate $(\%)^{\mathrm{j}}$ & $\begin{array}{l}\text { low (mean 23.6; range: } 0-36.2 \text {; median } 28.0 \text { ) } \\
\text { medium (mean 48.0; range: } 37.2-54.1 \text {; median } 49.9 \text { ) } \\
\text { high (mean } 61.8 \text {; range: } 55.4-68.3 \text {; median } 61.4 \text { ) }\end{array}$ & $\begin{array}{l}38 / 136 \\
41 / 261 \\
15 / 101\end{array}$ & $\begin{array}{l}24.2 \\
11.6 \\
8.0\end{array}$ & $\begin{array}{l}16.9-33.4 \\
7.1-18.3 \\
3.5-17.1\end{array}$ & 10.1 & 0.006 & 0.6 & $0.4-0.9$ & 0.007 \\
\hline
\end{tabular}

a Categories: low included vales $\leq 25$ th centile; medium - values between 25 th and 75 th centile; and high $\geq 75$ th centile.

${ }^{b}$ Number of IBR gB ELISA seropositive cervids/all animals tested in the category.

${ }^{\mathrm{c}}$ Estimated using sampling weights ( $1 /(\mathrm{n}$ of tested individuals/ $N$ of free-ranging cervids per district).

d $95 \%$ confidence interval.

e Chi-squared corrected for ties generated using Kruskal-Wallis rank test.

${ }^{\text {f }}$ Significance level at $P<0.05$ considered significant.

${ }^{\mathrm{g}}$ Number of animals $/ \mathrm{km}^{2}$ at the forest district level

h At the forest district level.

${ }^{\mathrm{i}}$ Number of animals/100 ha of agricultural areas at the province level.

${ }^{\mathrm{j}}$ At the county level.

doubtful results, however they were later confirmed to be positive against CvHV-1 in VNT, therefore those samples were considered positive in further analysis.

\subsection{Free-living cervids}

IBR gB ELISA seropositive deer were found in 32 out of $59(54.2 \%)$ forest districts (Fig. 1). The district seroprevalence ranged between 0 and $100 \%$, with the mean value of $17.4 \%$ (95\%CI: $10.1-24.0)$. The seroprevalence, which was also province dependent $\left(\chi^{2}=35.0\right.$; $P=0.0001)$ showed the mean value of $14.3 \%$ (95\%CI: $7.1-21.4$ ) and ranged between 0 and $39.2 \%$. The distribution of BoHV-1 seroprevalence (calculated using forest district sampling weights) according to different individual or geographical characteristics was presented in Table 1. The strongest association between BoHV-1 seroprevalence and species was depicted by the highest seropositivities among red deer (25.6\%) and fallow deer (23.1\%), and the lowest among the roe deer (1.7\%). The nominal level of afforestation and urbanization rate have also shown significant associations with the seroprevalence, however the effects of both were opposite (Table 1). In other words, the seroprevalence increased with afforestation, while it decreased with urbanization. The categorical covariate of province-level density of cattle has also showed some association with the seroprevalence; however, it was marginally significant $(P=0.08)$ when assessed by logarithmic regression. Sex and density of cervids were not found to be connected to the seroprevalence. In addition, the dependence of the seroprevalence on continuous variables such as density of cattle $\left(\chi^{2}=7.0 ; P=0.008\right)$ and afforestation $\left(\chi^{2}=7.5 ; P=0.006\right)$ have also been shown significant in the univariable analysis. The final mixed effect multivariable logistic regression model included species and urbanization rate (Table 2). The data clustered at the forest district level, therefore the variable was included as a random effect in the model. The risk of alphaherpesvirus seropositivity increased 10.6-fold in fallow deer and 11.9-fold in red deer in respect to the roe deer.
Furthermore, the risk of obtaining IBR gB ELISA seropositive result in deer decreased by 0.4 -fold in the medium and 0.3-fold in highly urbanized areas compared to the ones with low urbanization rate.

\subsection{Captive cervids}

Significant differences in IBR gB ELISA seroprevalence between species and individual herds were observed. In general, the highest seroprevalence has been found for red deer (27.0\%) and herd B (66.8\%); however, the analysis of the association of joint species and herd variable has shown more complex relationships (Table 3). Although, the proportion of seropositive red deer in herd $B$ reached $74.5 \%$, none of the red deer in herd A had detectable antibodies. Moreover, only $1.8 \%$ of fallow deer in herd B were found seropositive.

\subsection{VNT results}

All 20 samples negative in IBR gB ELISA were also negative in VNT. Four out of 177 tested samples that were positive or doubtful in IBR gB ELISA, gave negative results in VNT. In this group, one was previously doubtful in ELISA, while the rest was positive. The titres of positive sera against BoHV-1 ranged between 2 and 64. All 177 sera including 5 ELISA doubtful ones were found seropositive against CvHV-1 with the titres between 16 and 512 . The mean antibody titre against CvHV-1 (161.8; 95\%CI: 146.0-177.6) has been significantly higher than the mean titre of BoHV-1 antibodies (10.1; 95\%CI: 8.9-11.4) with $t$ value of -18.9 ( $\mathrm{P}<0.0001)$. The same was observed independently for each cervid species and type of population (free-ranging/captive) (Table 4). The distribution of neutralizing titres against both viruses depending on the species and population has been presented at the box plots at Fig. 2. Once again, the CvHV-1 titres were higher in respect to BoHV-1 in both captive and free-ranging red deer. 


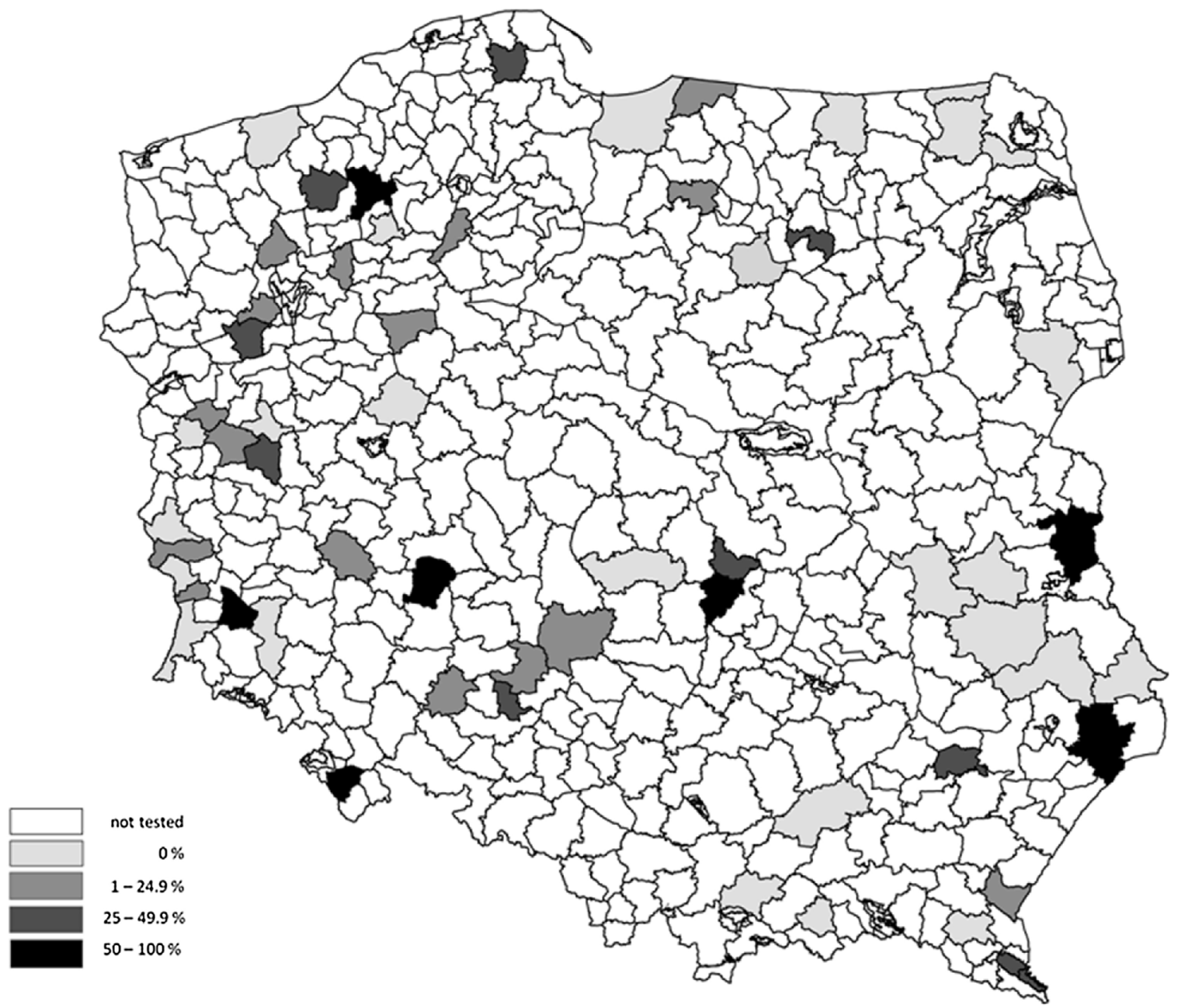

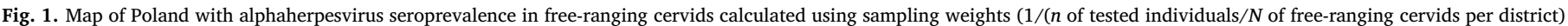
according to the forest district of origin.

\section{Discussion}

1 This study presents the first large-scale cross-sectional survey of alphaherpesvirus seroprevalence in Polish wild ruminants. Previously, only limited data on alphaherpesvirus infections in cervids in Poland was available. In two studies performed in 2011, small groups of freeranging red deer and roe deer from two locations were tested for the presence of antibodies against alphaherpesviruses but no seropositive animals were found (Rypuła et al., 2011a, 2011b; Salwa et al., 2011).
Our results confirmed that, the alphaherpesvirus infections are as frequent in the populations of both wild and farmed cervids in Poland as in other European countries such as Germany (Frölich et al., 2006), Czech Republic (Pospisil et al., 1996), Belgium or France (Thiry et al., 1988). The significant difference in the observed seroprevalence between wild and captive animals should be explained by different environment factors, and therefore each group was analyzed separately. Overall seroprevalence in captive animals was higher in comparison to free-ranging cervids. However, it should not be regarded as a general

Table 2

Mixed effects multivariable logistic regression model for analysis of risk factors of alphaherpesvirus seropositivity in free-living cervids.

\begin{tabular}{|c|c|c|c|c|c|c|}
\hline Variable & Category & Odds Ratio (OR) & $\beta(\mathrm{SE})^{\mathrm{c}}$ & $z$ & $P>|z|$ & $95 \% \mathrm{CI}^{\mathrm{b}}$ \\
\hline \multicolumn{7}{|l|}{ Species $^{\mathrm{a}}$} \\
\hline & Roe deer & reference & & & & \\
\hline & Fallow deer & 10.6 & 6.1 & 4.1 & $<0.0001$ & $3.4-32.8$ \\
\hline & Red deer & 11.9 & 5.4 & 5.4 & $<0.0001$ & $4.9-29.2$ \\
\hline \multicolumn{7}{|c|}{ Urbanization rate } \\
\hline & low & reference & & & & \\
\hline & medium & 0.4 & 0.1 & -3.2 & $<0.0001$ & $0.2-0.7$ \\
\hline & high & 0.3 & 0.1 & -3.3 & $<0.0001$ & $0.1-0.6$ \\
\hline \multirow[t]{2}{*}{ Random effect } & & Variance & $\beta(\mathrm{SE})^{\mathrm{c}}$ & $95 \% \mathrm{CI}^{\mathrm{b}}$ & & \\
\hline & forest district & 0.3 & 0.3 & $0.06-1.8$ & & \\
\hline
\end{tabular}

\footnotetext{
${ }^{\text {a }}$ Number of observations $=489$.

b Confidence interval.

c Standard error.
} 
Table 3

Descriptive univariable analysis of the BoHV-1 related alphaherpesvirus distribution among captive cervids $(n=696)$.

\begin{tabular}{|c|c|c|c|c|c|c|c|c|}
\hline \multirow[t]{2}{*}{ Variable } & \multirow[t]{2}{*}{ Category } & \multicolumn{3}{|c|}{ Seropositivity } & \multirow[t]{2}{*}{$\chi^{2 c}$} & \multirow[t]{2}{*}{$\mathrm{P}^{\mathrm{d}}$} & \multirow[t]{2}{*}{ Odds ratio (OR) } & \multirow[t]{2}{*}{ OR $95 \% \mathrm{CI}^{\mathrm{b}}$} \\
\hline & & $n / N^{\mathrm{a}}$ & $\%$ & $95 \% \mathrm{CI}^{\mathrm{b}}$ & & & & \\
\hline \multirow[t]{3}{*}{ Species } & Fallow deer (Dama dama) & $1 / 55$ & 1.8 & $0.04-9.7$ & 93.9 & 0.0001 & 2.4 & $1.5-3.9$ \\
\hline & Red deer (Cervus elaphus) & $367 / 618$ & 27.0 & $44.3-62.3$ & & & & \\
\hline & Dybowski's sika deer (Cervus nippon hortullorum) & $0 / 23$ & 0 & $0-1.5$ & & & & \\
\hline \multirow[t]{3}{*}{ Herd } & A herd & $0 / 113$ & 0 & $0-3.2$ & 179.3 & 0.0001 & 1.2 & $1.2-1.3$ \\
\hline & B herd & $349 / 522$ & 66.8 & $62.6-71.0$ & & & & \\
\hline & $C$ herd & $19 / 61$ & 31.1 & $19.9-44.3$ & & & & \\
\hline \multirow[t]{5}{*}{ Species_herd ${ }^{e}$} & Fallow deer_herd B & $1 / 55$ & 1.8 & $0.04-9.7$ & 283.7 & 0.0001 & 1.9 & $1.5-2.3$ \\
\hline & Red deer_herd A & $0 / 90$ & 0 & $0-4.0$ & & & & \\
\hline & Red deer_herd B & $119 / 348$ & 74.5 & $70.3-78.4$ & & & & \\
\hline & Red deer_herd C & $19 / 42$ & 31.1 & $19.9-44.2$ & & & & \\
\hline & Sika deer_herd A & $0 / 23$ & 0 & $0-1.5$ & & & & \\
\hline
\end{tabular}

${ }^{\text {a }}$ Number of IBR gB ELISA seropositive cervids/all animals tested in the category.

b $95 \%$ confidence interval.

${ }^{\mathrm{c}}$ Chi-squared corrected for ties generated using Kruskal-Wallis equality of population rank test.

d Significance level $(P<0.05$ was considered significant).

e New variable created by concatenating categorical variables of herd and species.

Table 4

Results of virus neutralization test (VNT) of ELISA positive samples against BoHV-1 and CvHV-1.

\begin{tabular}{|c|c|c|c|c|c|c|}
\hline \multirow[t]{2}{*}{ Variable } & \multirow[t]{2}{*}{ Category } & \multirow{2}{*}{$\begin{array}{l}\text { Number } \\
\text { of } \\
\text { samples }\end{array}$} & \multicolumn{2}{|l|}{ VNT } & \multirow[t]{2}{*}{$t$ value } & \multirow[t]{2}{*}{$P^{\mathrm{a}}$} \\
\hline & & & $\begin{array}{l}\text { Mean } \\
\text { titre } \\
\text { against } \\
\text { BoHV-1 }\end{array}$ & $\begin{array}{l}\text { Mean } \\
\text { titre } \\
\text { against } \\
\text { CvHV-1 }\end{array}$ & & \\
\hline \multirow[t]{3}{*}{ Species } & Fallow deer & 7 & 8.6 & 96 & -5.5 & 0.0001 \\
\hline & Red deer & 166 & 10.4 & 165.8 & -18.3 & $<0.0001$ \\
\hline & Roe deer & 4 & 5 & 112 & -6.6 & 0.0006 \\
\hline \multirow[t]{2}{*}{ Population } & Free-living & 59 & 7.4 & 128.5 & -12.7 & $<0.0001$ \\
\hline & Captive & 118 & 11.5 & 178.4 & -15.5 & $<0.0001$ \\
\hline
\end{tabular}

${ }^{\text {a }}$ Value of 0.05 was considered significant. Two-sample $t$ test was used to compare the means in each group.

rule, since results varied in the previous studies. For example in the study performed in Scotland (Nettleton et al., 1986), seroprevalence was lower in the deer farms. Since the animals are kept in the fenced areas, the spread within the farm might be faster due to the higher concentration of animals; however, the transmission of the pathogen into the population might be dependent mostly on the management and human involvement and there would be high variability in the exposure at the herd level. Significant differences observed between three herds included in the study were most probably caused by the different breeding approach. Herds B and C with high number of seropositive deer were commercial farms, to which imported animals are regularly introduced in order to enrich the genetic pool of the herd. As they are not routinely tested for antibodies against alphaherpesviruses before introduction, infected animals could be the major source of outbreaks in herds as it was observed previously both in case of CvHV-1 (Nettleton et al., 1986) and BoHV-1 (Wentink et al., 1993). In contrast, herd A, where no seropositive animals were found, is a self-sufficient breeding farm maintained for research purposes, therefore the risk of virus introduction into this herd was rather low.

Since there was dependence between the seroprevalence in freeranging cervids and the origin of the animals, we decided to analyze several individual and geographical characteristics of the local populations in order to identify the possible risk factors. Most evident differences in alphaherpesvirus exposure were associated with the cervid species. Both univariable and multivariable statistical models confirmed that the exposure of red deer and fallow deer to BoHV-1

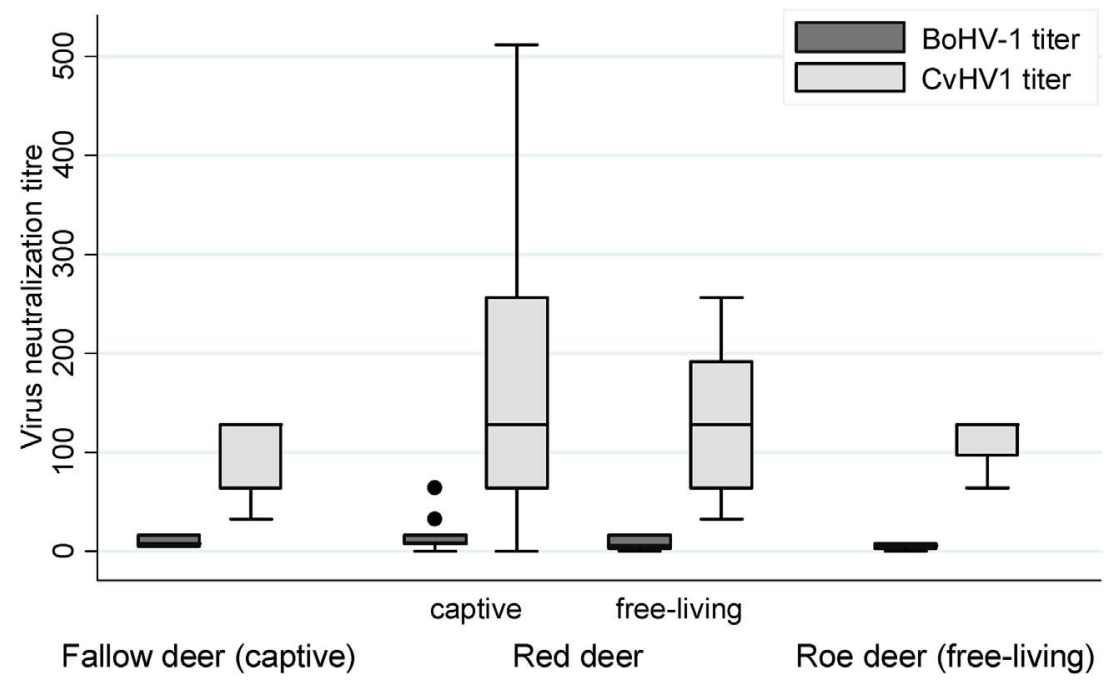

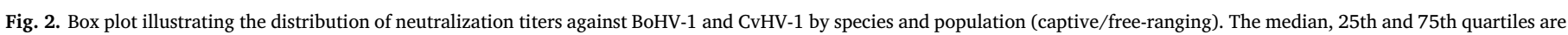
represented by the vertical lines of box, while the whiskers indicate the max and min values. 
related alphaherpesvirus was more frequent than in roe deer. Similar observations were made previously in France, Belgium, and Germany (Thiry et al., 1988; Frölich et al., 2006). On the other hand, Lillehaug et al. (2003) did not see any difference between BoHV-1 seropositivity in Norwegian red deer and roe deer. In the same time, over $28 \%$ of freeranging reindeer, the most abundant deer species in Norway, were exposed to a BoHV-1 related alphaherpesvirus, most likely CvHV-2 which is an alphaherpesvirus specific of reindeer. Several explanations of the low seroprevalence in roe deer was proposed. It was suggested that social behaviour of red deer, which contrary to roe deer tend to live in large groups throughout the whole year and migrate further between different regions, could facilitate contacts between different populations and consequently spread of the viruses in population. Alternatively, roe deer may be less susceptible to infections with alphaherpesviruses (Frölich et al., 2006) as it represents different phylogenetic subfamily of Cervidae compared to red deer and fallow deer. It is possible that roe deer belonging to Caprealinae subfamily lack some of the virus receptors present in Cervinae subfamily. More surprising was the high seroprevalence among fallow deer $(23.1 \%)$, whereas it was lower than $5 \%$ in most of the previous studies (Nettleton et al., 1988; Frölich et al., 2006). It is possible that our results could have been distorted by the relatively low number of fallow deer tested with almost half of the positive samples originating from animals living in the same forest district.

Significant association was also observed between the seroprevalence and level of afforestation and urbanization in forest districts. Multivariable logistic regression model for analysis of influence of urbanization as a risk factor showed that regions with high urbanization are characterized by a lower risk of alphaherpesvirus infections and inversely, forest districts with higher proportion of forest area were characterized by a higher seroprevalence. Most probably both of those risk factors are connected with the influence that urbanization and afforestation have on the dynamics, space use and habitat selection of wild cervid populations. In the highly urbanized regions, the habitats become fragmented as deer tend to avoid developed areas (Vogel, 1989; Theobald et al., 1997), which in result may limit contacts between different subpopulations and consequently disturb further viral spread. Conversely higher afforestation might provide convenient corridors for movement of animals those increasing frequencies of contacts between subpopulations.

Although no correlation between density of cattle and seroprevalence of alphaherpesviruses in cervids was observed previously (Frölich, 1996), univariable statistical analysis of our results showed some marginal correlation. Especially, in provinces with high density of cattle, seroprevalence in cervids was also high. However, cattle density has been excluded from the final model, since it was proven insignificant for the seroprevalence. Inferring simple associations between domestic ruminant density and increased chance of transmission of alphaherpesviruses between cervids and livestock may be false. Previous studies proved that, although cervids are in limited degree susceptible to BoHV-1 infection, transmission through direct contact with cattle is very unlikely (Mollema et al., 2005; Nettleton et al., 1988). On the other hand, Frölich et al. (2006) have suspected this kind of transmission between red deer reared in two German national parks and local cattle population. An indication that the strain circulating in Polish cervids is a species-specific endemic alphaherpesvirus, overruling a possibility of spill over effect from cattle was given in the crossneutralization tests. As commercial IBR gB blocking ELISA kits are specific to a wide range of ruminant alphaherpesviruses (Neves et al., 2009), high quality, BoHV-1 seropositive serum samples were selected for further analysis by VNT in order to determine if cervids tested positively due to an infection with BoHV-1 or CvHV-1. Although the majority of the tested serum samples neutralized BoHV1 and CvHV-1, the individual and the mean titres against CvHV-1 were much higher than against BoHV-1. To summarize, it is highly improbable that observed borderline correlation between cattle density and seropreva- lance among cervids has any revelance. Instead, it could rather stem from correlation between cattle density and different environmental factor that directly influence the spread of alphaherpesvirus in cervid population.

It is noteworthy that although only CvHV-1 was demonstrated to be capable of causing clinical signs in cervids (Thiry et al., 1988) in some cervid populations, antibodies against different alphaherpesviruses were previously reported. For example, in a study of cervid populations from National Parks in Germany by Frölich et al. (2006), the highest seroprevalence was recorded against BoHV-1, whereas in earlier German study highest titres were found against caprine herpesvirus 1 (CpHV-1) Frölich, 1996.

In conclusion, our results showed that BoHV-1 related alphaherpesvirus infections are present in population of free-ranging and farmed cervids in Poland. However, based on the viral neutralisation test it seems that dominant virus circulating in wild ruminants is CvHV-1, therefore it is highly unlikely that deer in Poland could play any role as a reservoir of BoHV-1 to cattle.

\section{Competing interests}

The authors declare that they have no competing interests.

\section{Acknowledgements}

The authors wish to thank Elwira Orłowska and Małgorzata Głowacka for their technical assistance. This study was supported by NCBiR project NR12-0126-10.

\section{References}

Baczyński, Z., Majewska, H., 1977. Virological characteristics of bull semen originating from a herd infected with bovine rhinotracheitis/infectious pustular vulvovaginitis virus (IBR/IPV). Bull. Vet. Inst. Pulawy 21, 79-81.

Central Statistical Office (CSO), 2013. http://stat.gov.pl/en/topics/agriculture-forestry/ agriculture/agriculture-in-2013,4,10.html.

CSO, 2013. Local Data Bank: Urban population in\% of total population: http://stat.gov. $\mathrm{pl} /$ bdlen/app/strona.html?p_name = indeks.

Davison, A.J., 2010. Herpesvirus systematics. Vet. Microbiol. 143, 52-69.

Dohoo, I.R., Martin, W., Stryhn, H., 2010. Veterinary Epidemiologic Research, 2nd edition. Atlantic Veterinary College Inc., University of Prince Edward Island, Prince Edward Island, Canada 865 pp.

Frölich, K., Hamblin, C., Parida, S., Tuppurainen, E., Schettler, E., 2006. Serological survey for potential disease agents of free-ranging cervids in six selected national parks from Germany. J. Wildl. Dis. 42, 836-843.

Frölich, K., 1996. Seroepizootiologic investigations of herpesviruses in free-ranging and captive deer (Cervidae) in Germany. J. Zoo Wildl. Med. 27, 241-247.

General Directorate of National Forest Holding (GDNFH), 2014. The summary of the hunting plans for 2013/2014. National Forestry Database (SILP)

Inglis, D.M., Bowie, J.M., Allan, M.J., Nettleton, P.F., 1983. Ocular disease in red deer calves associated with a herpesvirus infection. Vet. Rec. 113, 182-183.

Intisar, K.S., Ali, Y.H., Khalafalla, A.I., Mahasin, E.A., Amin, A.S., 2009. Natural exposure of Dromedary camels in Sudan to infectious bovine rhinotracheitis virus (bovine herpes virus-1). Acta Trop. 111, 243-246.

Kálmán, D., Egyed, L., 2005. PCR detection of bovine herpesviruses from nonbovine ruminants in Hungary. J. Wildl. Dis. 41, 482-488.

Kita, J., Anusz, K., 1991. Serologic survey for bovine pathogens in free-ranging European bison from Poland. J. Wildl. Dis. 27, 16-20.

Kita, J., 1978. Izolacja wirusa zakaźnego zapalenia nosa i tchawicy (IBR) z ogniska bronchopneumonii młodego bydła. Med. Weter. 34, 723-725.

Lillehaug, A., Vikøren, T., Larsen, I.L., Akerstedt, J., Tharaldsen, J., Handeland, K., 2003. Antibodies to ruminant alpha-herpesviruses and pestiviruses in Norwegian cervids. J. Wildl. Dis. 39, 779-786.

Mollema, L., Rijsewijk, F.A., Nodelijk, G., de Jong, M.C., 2005. Quantification of the transmission of bovine herpesvirus 1 among red deer (Cervus elaphus) under experimental conditions. Vet. Microbiol. 111, 25-34.

Muylkens, B., Thiry, J., Kirten, P., Schynts, F., Thiry, E., 2007. Bovine herpesvirus 1 infection and infectious bovine rhinotracheitis. Vet. Res. 38, 182-209.

Nandi, S., Kumar, M., Manohar, M., Chauhan, R.S., 2009. Bovine herpes virus infections in cattle. Anim. Health Res. Rev. 10, 85-98.

Nettleton, P.F., Sinclair, J.A., Herring, J.A., Inglis, D.M., Fletcher, T.J., Ross, H.M., Bonniwell, M.A., 1986. Prevalence of herpesvirus infection in British red deer and investigations of further disease outbreaks. Vet. Rec. 118, 267-270.

Nettleton, P.F., Thiry, E., Reid, H., Pastoret, P.P., 1988. Herpesvirus infections in cervidae. Rev. Sci. Tech. Off. Int. Epiz. 7, 977-988.

Neves, C.G.D., Roger, M., Yoccoz, N.G., Rimstad, E., Tryland, M., 2009. Evaluation of 
three commercial bovine ELISA kits for detection of antibodies against

Alphaherpesviruses in reindeer (Rangifer tarandus). Acta Vet. Scand. 51, 9.

Pospisil, Z., Vyvlecka, R., Cihal, P., Lany, P., Zendulkova, D., 1996. Detection of herpesvirus serum antibodies in red deer (Cervus elaphus) imported into the Czech Republic. Vet. Med.-Czech. 41, 279-282.

Roizmann, B., Desrosiers, R.C., Fleckenstein, B., Lopez, C., Minson, A.C., Studdert, M.J., 1992. The family herpesviridae: an update: the herpesvirus study group of the international committee on taxonomy of viruses. Arch. Virol. 123, 425-449.

Rola, J., Polak, M.P., Zmudziński, J.F., 2005. Specific immunoprophylaxis of some viral diseases in cattle. Pol. J. Vet. Sci. 8, 315-321.

Rypuła, K., Krasińska, M., Kita, J., 2011a. The occurrence of alpha-herpesvirus and pestivirus infections in European bison (Bison bonasus) in the Bialowieza Primeval Forest. Eur. Bison Conserv. Newsl. 4.

Rypuła, K., Krasińska, M., Kita, J., Płoneczka-Janeczko, K., Kapuśniak, W., 2011b. The prevalence of specific antibody to selected viral and bacterial infections in wild ruminants in Poland. Eur. J. Immunol. 36, 180-183.

Rypuła, K., Płoneczka-Janeczko, K., Kita, J., Kumala, A., Zmudziński, J.F., 2012. Seroprevalence of BHV-1 (bovine herpesvirus type 1) among non-vaccinated dairy cattle herds with respiratory disorders. Pol. J. Vet. Sci. 15, 561-563.

Salwa, A., Anusz, K., Arent, Z., Paprocka, G., Kita, J., 2007. Seroprevalence of selected viral and bacterial pathogens in free-ranging European bison from the Białowieza
Primeval Forest (Poland). Pol. J. Vet. Sci. 10, 19-23.

Salwa, A., Anusz, K., Welz, M., Wozikowski, R., Zaleska, M., Kita, J., 2011. Analiza sytuacji epizootiologicznej u zwierząt gospodarskich i wolno żyjących w

Bieszczadach w związku wystapieniem gruźlicy bydlęcej u żubrów (Bison bonasus). Eur. Bison Conserv. Newsl. 4, 71-80.

Scicluna, M.T., Caprioli, A., Saralli, G., Manna, G., Barone, A., Cersini, A., Cardeti, G., Condoleo, R.U., Autorino, G.L., 2010. Should the domestic buffalo (Bubalus bubalis) be considered in the epidemiology of Bovine Herpesvirus 1 infection? Sens. Actuators Microbiol. 143, 81-88.

Theobald, D.M., Miller, J.R., Hobbs, N.T., 1997. Estimating the cumulative effects of development on wildlife habitat. Landsc. Urban Plan. 39, 25-36.

Thiry, E., Vercouter, M., Dubuisson, J., Barrat, J., Sepulchre, C., Gerardy, C., Pastoret, P.P., 1988. Serological survey of herpesvirus infections in wild ruminants of France and Belgium. J. Wildl. Dis. 24, 268-273.

Thiry, J., Keuser, V., Muylkens, B., Meurens, F., Gogev, S., Vanderplasschen, A., Thiry, E., 2006. Ruminant alphaherpesviruses related to bovine herpesvirus 1. Vet. Res. 37, 169-190.

Vogel, W.O., 1989. Response of deer to density and distribution of housing in montana. Wildl. Soc. B 17, 406-413.

Wentink, G.H., Van Oirschot, J.T., Verhoeff, J., 1993. Risk of infection with bovine herpes virus 1 (BHV1): a review. Vet. Q. 15 (1), 30-33. 